\title{
Correction to: Allogeneic hematopoietic stem cell transplantation in two brothers with DNA ligase IV deficiency: a case report and review of the literature
}

\author{
Sarah Schober ${ }^{1}$, Karin Schilbach ${ }^{1}$, Michaela Doering ${ }^{1}$, Karin M. Cabanillas Stanchi ${ }^{1}$, Ursula Holzer ${ }^{1}$, \\ Patrick Kasteleiner ${ }^{1}$, Jens Schittenhelm² ${ }^{2}$ Juergen F. Schaefer ${ }^{3}$, Ingo Mueller ${ }^{4}$, Peter Lang ${ }^{1}$ and \\ Rupert Handgretinger ${ }^{1 *}$
}

\section{Correction to: BMC Pediatr (2019) 19:346 https://doi.org/10.1186/s12887-019-1724-z}

After publication of the original article [1], it was brought to our attention that references 24 and 31 are cited incorrectly in the article.

Reference '[2]' (see reference list below) should be cited where reference 24 is cited; NB the correct reference [2] is missing in the original article.

While reference '[3]' (see reference list below) should be cited where reference 31 is cited; NB the correct reference [3] is present in the original article, but in the original article it is reference '29'.

The authors apologize for any inconvenience caused.

\section{Author details}

'Department I - General Pediatrics, Hematology/Oncology, University Children's Hospital Tuebingen, Hoppe-Seyler-Str.1, 72076 Tuebingen, Germany. ${ }^{2}$ Department of Neuropathology, Institute of Pathology and Neuropathology, Eberhard-Karls University Tuebingen, Calwer Str. 3, 72076 Tuebingen, Germany. ${ }^{3}$ Department of Diagnostic and Interventional Radiology, University Hospital Tuebingen, Hoppe-Seyler-Str. 3, 72076 Tuebingen, Germany. ${ }^{4}$ Division for Pediatric Stem Cell Transplantation and Immunology, Clinic for Pediatric Hematology and Oncology, University Medical Center Hamburg-Eppendorf, Martinistr. 52, 20246 Hamburg, Germany.
Published online: 02 December 2019

References

1. Schober S, Schilbach K, Doering M, Cabanillas Stanchi KM, Holzer U, Kasteleiner $\mathrm{P}$, et al. Allogeneic hematopoietic stem cell transplantation in two brothers with DNA ligase IV deficiency: a case report and review of the literature. BMC Pediatr. 2019;19(1):346. https://doi.org/10.1186/s12887-019-1724-z.

2. Yue J, Lu H, Lan S, Liu J, Stein MN, Haffty BG, et al. Identification of the DNA repair defects in a case of Dubowitz syndrome. PLoS One. 2013;8(1):e54389.

3. Cowan MJ, Gennery AR. Radiation-sensitive severe combined immunodeficiency: the arguments for and against conditioning before hematopoietic cell transplantation--what to do? J Allergy Clin Immunol. 2015;136(5):1178-85

\footnotetext{
* Correspondence: rupert.handgretinger@med.uni-tuebingen.de The original article can be found online at https://doi.org/10.1186/s12887019-1724-z

1'Department I - General Pediatrics, Hematology/Oncology, University Children's Hospital Tuebingen, Hoppe-Seyler-Str.1, 72076 Tuebingen, Germany

Full list of author information is available at the end of the article
}

(c) The Author(s). 2019 Open Access This article is distributed under the terms of the Creative Commons Attribution 4.0 International License (http://creativecommons.org/licenses/by/4.0/), which permits unrestricted use, distribution, and reproduction in any medium, provided you give appropriate credit to the original author(s) and the source, provide a link to the Creative Commons license, and indicate if changes were made. The Creative Commons Public Domain Dedication waiver (http://creativecommons.org/publicdomain/zero/1.0/) applies to the data made available in this article, unless otherwise stated. 